Acta vet. scand. $1967,8,86-87$.

Brief Communication

\title{
SENSITIVITY OF SUCKLING MICE TO VARIOUS STRAINS OF INFECTIOUS BRONCHITIS VIRUS
}

Suckling mice are serviceable in many virological experiments because they are sensitive to various virus species. Simpson $\&$ Groupe (2) succeeded in adapting the Beaudette strain of infectious bronchitis virus (IBV) to suckling mice, using the intracerebral route of inoculation. A study of the properties of a Finnish strain of infectious bronchitis virus $\left(\mathrm{IBV}_{\mathrm{F}}\right)$ has been published recently (1). It successfully established the intracerebral adaptation of $\mathrm{IBV}_{\mathrm{F}}$ to suckling mice. The suckling mice were $100 \%$ sensitive to this virus strain up to an age of 12 days. Symptoms of the central nervous system with a typical clearly discernible gibbosity in the vertebral column were elicited after an incubation period of $2-3$ days, and the animals died 3-4 days after the inoculation. Parallelly with $\mathrm{IBV}_{\mathrm{F}}$, transmission experiments with other IBV strains were carried out. The present paper is a report on the results of these experiments.

Material and Method. The following IBV strains used were obtained by courtesy of Dr. S. B. Hitchner, Berlin Biological Laboratories, Berlin, Maryland: IBV Beaudette $\left(\operatorname{IBV}_{B}\right)$; IBV Massachusetts $\left(\mathrm{IBV}_{M}\right)$; IBV Connecticut $\left(\mathrm{IBV}_{\mathrm{C}}\right)$; IBV Iowa $97\left(\mathrm{IBV}_{\mathrm{I}-97}\right)$; IBV Iowa 609 $\left(\operatorname{IBV}_{\mathrm{I}-609}\right)$; IBV Holte $\left(\mathrm{IBV}_{\mathrm{H}}\right)$ and IBV Gray $\left(\mathrm{IBV}_{\mathrm{G}}\right)$.

The mice were of the Swiss Albino Webster strain from the State Veterinary Medical Institute, Helsinki. They were inoculated intracerebrally at 4 days of age with virus-containing undiluted allantoic fluids or with $10 \%$ brain suspensions, dose $0.02 \mathrm{ml}$. The virus-containing allantoic fluids used in primary mouse transfers derived from earlier egg passages with the IBV strains. The virus titres of the allantoic fluids were in the range of $10^{4}-106.5 \mathrm{EID}_{50}$ per ml. The subpassages in mice were carried out with suspensions made from mouse brain from preceding passages.

Results. $\mathrm{IBV}_{\mathrm{B}}, \mathrm{IBV}_{\mathrm{M}}, \mathrm{IBV}_{\mathrm{I}-97}$ and $\mathrm{IBV}_{\mathrm{G}}$ were successfully adapted to suckling mice. Adaptation failed with $\mathrm{IBV}_{\mathrm{C}}, \mathrm{IBV}_{\mathrm{I}-609}$ and $\mathrm{IBV}_{\mathbf{H}}$. The mouse-adapted strains produced in mice the same clinical pattern as described previously as a property of $\mathrm{IBV}_{\mathrm{F}}$ (1). A $100 \%$ lethality was achieved with $\mathrm{IBV}_{\mathrm{I}-97}$ already in the first mouse transfer. Compatible results were obtained with $\mathrm{IBV}_{\mathrm{B}}$ and $\mathrm{IBV}_{M}$ in the second and with $\mathrm{IBV}_{G}$ in the fourth mouse passage. 
Eight mouse passages were carried out with every virus strain. The IBV content of the mouse passages were controlled in 9-dayold chicken embryos. The tests were performed either from brain suspensions of dead or in a comatose condition decapitated mice, or in passages with unadapted strains from clinically healthy 10-day-old mice. Positive isolation results were obtained only from mouse passages inoculated with IBV strains which were adaptable to suckling mice.

Discussion. The sensitivity of suckling mice to different IBV strains varied distinctly. Of 7 strains examined, 4 were readily adapted to them. Suckling mice seem to be suitable for studies of IBV and for comparison of its various strains.

T. Estola

State Veterinary Medical Institute,

Helsinki, Finland

\section{REFERENCES}

1. Estola, T.: Studies on the infectious bronchitis virus of chickens isolated in Finland with reference to the serological survey of its occurrence. Acta vet. scand. 1966, suppl. 18.

2. Simpson, A. W. \& V. Groupé: Temperature of incubation as a critical factor in the behavior of avian bronchitis virus in chicken embryos. Virology 1959, 8, 456-469. 
